\title{
Time- and size-resolved bacterial aerosol dynamics in highly polluted air: new clues for haze formation mechanism
}

Ting Zhang, Xinyue Li, Minfei Wang, Haoxuan Chen and Maosheng Yao* State Key Joint Laboratory of Environmental Simulation and Pollution Control, College of Environmental Sciences and Engineering, Peking University, Beijing 100871, China

\section{* Corresponding Author:}

Maosheng Yao, PhD Boya Distinguished Professor State Key Joint Laboratory of Environmental Simulation and Pollution Control, College of Environmental Sciences and Engineering, Peking University, Beijing 100871, China

Email: yao@pku.edu.cn

Ph: +8601062767282

Submitted to

bioRxiv

Jan 6, 2019

Beijing, China 


\section{Abstract}

Aerosol chemistry is often studied without considering microbial involvements. Here, we have applied a high-volume $\left(1 \mathrm{~m}^{3} / \mathrm{min}\right)$ aerosol sampler and the MicroOrifice Uniform Deposit Impactor (NanoMoudi) along with molecular and microscopic methods to investigate time-and size-resolved bacterial aerosol dynamics in air. Under high particulate matter (PM) polluted episodes, bacterial aerosols were detected to have a viability up to $50-70 \%$ in the $0.56-1 \mu \mathrm{m}$ size range, at which elevated levels of $\mathrm{SO}_{4}^{2-}, \mathrm{NO}^{3-}$ and $\mathrm{NH}^{4+}$ were concurrently observed. Engineered or acclimated for both pharmaceuticals and wastewater treatment, bacteria such as Psychrobacter spp., Massilia spp., Acinetobacter Iwoffii, Exiguobacterium aurantiacum, and Bacillus megaterium were shown to have experienced massive abundance shifts in polluted air on early mornings and late afternoons, on which were previously reported to witness rapid new particle formation events. For example, Acinetobacter spp. were shown to account for $>96 \%$ abundance at a corresponding $\mathrm{PM}_{2.5}$ level of $208 \mu \mathrm{g} / \mathrm{m}^{3}$. The bacterial aerosol changes corresponded to the observed $\mathrm{PM}_{2.5}$ mass peak shift from 3.2-5.6 $\mu \mathrm{m}$ to the high viability size range of $0.56-1 \mu \mathrm{m}$. Additionally, it is interesting that elevated levels of soluble $\mathrm{Na}, \mathrm{Ca}, \mathrm{Mg}, \mathrm{K}, \mathrm{Al}, \mathrm{Fe}$ and $\mathrm{P}$ elements that are required for bacterial growth were observed to co-occur with those significant bacterial aerosol structure shifts in the air. For particular time-resolved $\mathrm{PM}_{2.5}$ pollution episodes, Acinetobacter and Massilia were shown to alternate in dominating the time-resolved aerosol community structures. The results from a HYSPLIT trajectory model simulation suggested that the role by air mass transport in affecting the observed bacterial 
aerosol dynamics could be minor. As an evidence, we found that Acinetobacter, Psychrobacter, Exiguobacterium, and Bacillus genera were emitted into the air with a level of $>3000 \mathrm{CFU} / \mathrm{m}^{3}$ from a pharmaceutical plant. In addition, high level of VOCs up to 15,030 ppbv, mainly Acetone (61\%) and Acetaldehyde (11\%), were also detected in the air inside the plant. All the data including size-resolved viability and time-resolved bacterial aerosol dynamics together with their growth conditions detected in the air suggested that airborne bacteria in the size range of $0.56-1 \mu \mathrm{m}$ could have played important roles for haze formation in Beijing. The results about time- and size-resolved bacterial aerosol dynamics from this work provide a fresh understanding of aerosol chemistry especially in highly polluted air. It is hoped that these findings could lend a support in future cost-effective air pollution control practices.

Keywords: Bacterial aerosol dynamics in the air, Particulate matter, Size-and Timeresolved bacterial aerosol, Aerosol chemistry

\section{Introduction}

Air pollution has become one of serious environmental challenges facing mankind in modern society. Among many others, the core question about air pollution episode is : what is the driving force for accelerating the rapid fine particle growth in typical haze events? Regarding the $\mathrm{PM}_{2.5}$ precursor VOC, some studies report that current models underestimate atmospheric $\mathrm{VOC}$ emission and also $\mathrm{OH}$ radical reactivity(Whalley et al., 2016). Experiments have shown that a direct source of 
extremely low volatile organic compounds, i.e., a possible new particle formation precursor, was observed from the $\mathrm{OH}$ oxidation of acyclic and exocyclic terpenes and isoprene (Jokinen et al., 2015). In another work, it was found that the new particle formation rate, in addition to one-hour lag in time compared to the observation, in the size range of 6-10 $\mathrm{nm}$ was significantly underestimated by WRF-Chem and MALTE-BOX models(Huang et al., 2016). These studies collectively imply that there are some uncertainties and unexpected outcomes in measurements of VOCs, new particles and $\mathrm{OH}$ reactivity by both aerosol chemistry models and field campaigns.

Although biological materials such as bacteria are increasingly being investigated during haze episodes, their roles in the $\mathrm{PM}_{2.5}$ formation have never been studied or considered. Thus, it is completely unclear if the biological materials have a role in the haze occurrence. In the past, during the haze episodes the levels of fluorescent bioaerosol (described to be viable) particles were shown to be elevated in the size ranges of less than $1 \mu \mathrm{m}$ (Wei et al., 2016). In addition, endotoxin, an important bacterial membrane component, was also shown to be twice that on clear days(Wei et al., 2016). In other studies, culturable bacterial levels were shown to be higher during the haze periods than those during clear days(Liu et al., 2018;Gao et al., 2016;Gao et al., 2015a;Cao et al., 2014). Among the bacterial genera, Bacillales, Actinomycetales, Pseudomonadales were detected to dominate the community(Cao et al., 2014;Pöschl et al., 2010). For climate, evidences show that certain bacteria could serve as an ice nucleator or cloud condensation nuclei (Fröhlich-Nowoisky et al., 
2016;Šantl-Temkiv et al., 2015;Pöschl et al., 2010), and they might undergo metabolisms even at lower temperatures(Price and Sowers, 2004). Unfortunately, all these studies did not consider the microbial roles in atmospheric aerosol chemistry or the formation of haze episodes.

Here, this work was conducted to investigate the following questions: 1) if certain bacteria experience a rapid massive increase at particular times in highly polluted air?; 2) If so, in which size and what are the species?; 3) Are there any differences in bacterial dynamics during day and night time for a typical haze episode? ; 4) If bacterial growth conditions are available in highly polluted air? The answers to these questions will be of great value in providing new insights on the long-sought haze formation mechanism.

\section{Materials and methods}

\subsection{Particulate matters (PM) collection}

\subsubsection{PM sample collection using the NanoMoudi}

Size-resolved particulate matter samples were collected using Micro-Orifice Uniform Deposit Impactor (NanoMoudi) (MSP, USA) with 13 stages (stage 1: 10-18 $\mu$ m; stage 2: 5.6-10 $\mu \mathrm{m}$;stage 3: 3.2-5.6 $\mu \mathrm{m}$; stage 4: 1.8-3.2 $\mu \mathrm{m}$; stage 5: 1.0-1.8 $\mu \mathrm{m}$; stage 6: 0.56-1.0 $\mu \mathrm{m}$; stage 7: 0.32-0.56 $\mu \mathrm{m}$; stage 8: 0.18-0.32 $\mu \mathrm{m}$; stage 9: 0.1-0.18 $\mu \mathrm{m}$; stage 10: $0.056-0.01 \mu \mathrm{m}$; stage $11: 0.032-0.056 \mu \mathrm{m}$; stage $12: 0.018-0.032 \mu \mathrm{m}$; and stage 13: $0.01-0.018 \mu \mathrm{m})$ near the Environmental Building on Peking University 

experiment, six sets of samples were obtained on $47 \mathrm{~mm}$ (stage 1 to 10) and $90 \mathrm{~mm}$ the day-time (Day): from 7:00 AM to 7:00 PM, and the night-time (Night): from 8:00 PM to 6:00 AM. device were weighed using a microbalance after conditioned at constant temperature $\left(24.5^{\circ} \mathrm{C}\right)$ and humid $(50 \%)$ for at least $48 \mathrm{~h}$ in advance. The membrane with samples on each stage of the NanoMoudi was then placed into a $15 \mathrm{~mL}$ tube and soaked in 4 $\mathrm{mL} 0.05 \%$ tween 20 water, and the sealed tubes were placed at $4^{\circ} \mathrm{C}$ in a shaker operated with a rotation speed of 200 rpm continuously for 4 hours. Finally, all the well-mixed sample extracts were kept at $-20^{\circ} \mathrm{C}$ immediately before any analysis. For the quality controls, all aluminum membranes and the sampler were washed by absolute ethyl alcohol before use. And blank membranes without the air sampling were also brought to the sampling site which was later incorporated into the sample analysis as the negative control. 
period for each day in three different pollution episodes $\left(14-208 \mu \mathrm{g} / \mathrm{m}^{3}\right)$ using the HighBioTrap sampler (Beijing dBlue Tech, Inc, Beijing, China) at an air flow rate of 1000 $\mathrm{L} / \mathrm{min}$ for $20 \mathrm{~min}$ for each sample on Peking University campus $\left(40^{\circ} 00^{\prime} \mathrm{N}, 116^{\circ} 32^{\prime} \mathrm{E}\right)$.

The detailed sampling protocol was described for the HighBioTrap in our previous work(Chen and Yao, 2018). For each $\mathrm{PM}_{2.5}$ pollution episode, particulate matter samples were collected in duplicates using the HighBioTrap at an interval of every 2 or 4 hours on an aluminum membrane coated with $600 \mu \mathrm{L}$ mineral oil at a height of 1.5 $\mathrm{m}$ above the ground. Specific sampling times and meteorological conditions are provided in the Table S1 (Supporting Information). Here, two air samples with $20 \mathrm{~m}^{3}$ air were collected using the high-volume sampler for each specific time period. As a comparison, bacterial aerosol samples were also collected using the HighBioTrap in a pharmaceutical plant to study the bacterial emissions into the air. After each sampling, the mineral-oil-coated membrane was washed by $1.5 \mathrm{~mL} 0.05 \%$ tween 20 water, then the oil-in-water emulsion was centrifuged to remove the mineral oil supernatant at a speed of 7000 rpm using a centrifuge (5804r, Eppendorf, German). After a mixing process, the sample extracts were kept at $-20^{\circ} \mathrm{C}$ immediately before any analysis. For total bacteria and their community structures, 78 samples and 2 negative control samples (blank membrane samples) were analyzed using qPCR and Illumina platforms

155 (Sangon Biotech, Inc., Shanghai, China) as described in in Supplementary Text. Besides, bacterial species identifications were also performed using VITKE MS and MICROFLEX as described in Supplementary Text. As a comparison, air samples were also collected using the 4-Channel Particulate Matter Sampler as documented in Supplementary Text. 
Besides, air samples from a pharmaceutical plant were also collected using Silonite ${ }^{\mathrm{TM}}$

Classical Canisters (Entech Instruments, Simi Valley, CA 93065), and their corresponding volatile organic compounds (VOCs) levels were further analyzed (Wuhan Tianhong Instruments Co., Ltd.) according to a previously published protocol ${ }^{34}$.

\subsection{PM-borne Endotoxin assay using the LAL assay, bacterial viability using DNA}

stain method, and reactive oxygen species (ROS) using DL-Dithiothreitol (DTT) assay

Standard Endotoxin, CSE, Associate of Cape Cod, Inc., Eastham, MA, USA) by USA) was used in the assay according to the manufacturer's guidelines. The standards, negative controls and air samples were pre-incubated and analyzed using a microplate reader running SoftMaxPro 5.4.1 software (SpectraMax 340; Molecular Devices,

177 Sunnyvale, CA) with photometric measurements taken at $37^{\circ} \mathrm{C}$ every $1 \mathrm{~min}$ for $60 \mathrm{~min}$

178 at $405 \mathrm{~nm}$. The viability of bacteria in the particulate matters was studied using a 179 live/dead viability kit (L7012 BacLight Viability Kit, Invitrogen) as described in 
certain air samples collected were conducted using DTT assay and ICP-MS as documented in Supplementary Text.

\subsection{Air mass back-trajectory analysis with cluster}

Air mass transport for three-days was studied during certain air pollution episodes using HYSPLIT Trajectory Model(NOAA) via Hysplit 4 software. The climate data from GDAS1(ftp://arlftp.arlhq.noaa.gov/pub/archives/gdas1/) were used for simulation.

\section{Statistical analysis}

The mass distribution mode differences between the hazy day and clean day were analyzed by two-way ANOVA. Other difference analyses were performed using the paired t-test. All tests were performed using the statistical components from the SigmaPlot 12.5 software. Non-metric Multi-Dimensional Scaling (NMDS) based on Bray-Curtis distance was used to compare bacterial community structures among samples. NMDS was performed by $R$ software (version 3.2 ) with the vegan package

2.0-10. A p-value of 0.05 indicates a statistically significant difference in this work.

\section{Results and discussion}

\subsection{Size-resolved PM mass and composition during different pollution episodes}

Here, we presented our results about PM loading and bacterial aerosol increases 

from less than $30 \%$ to up to $90 \%$ of the total mass were detected in the size range of 0.56 to $1 \mu \mathrm{m}$ during the haze episodes $\left(\mathrm{PM}_{2.5}=91.33 \mu \mathrm{g} / \mathrm{m}^{3}\right)$ as observed in Figure 1 (A), seconded by those appearing in $0.32-0.56 \mu \mathrm{m}$ size range. For particles of $0.24-0.74$ $\mu \mathrm{m}$, their mass percentages all increased ( $p$-value<0.001; two-way ANOVA), but others did not decrease significantly ( $p$-value $=0.198-0.64$ ) as seen in Figure $1(A)$ during the haze episodes. The data observed in Figure $1(\mathrm{~A})$ are generally in line with other studies in which the same particle size range, i.e., 0.56-1 $\mu \mathrm{m}$, was detected to have the highest mass increases during typical high PM pollution episodes in Beijing (Sun et al., 2015; Yue et al., 2018). This phenomenon was also observed during the haze episodes in other places, such as Taiwan(Tsai et al., 2012) and Singapore(Behera et al., 2015), though different from the firework-caused air pollution scenario(Jing et al., 2014). Similarly, we have also observed that for both size ranges $(0.32-0.56 \mu \mathrm{m}$ and $0.56-1$ $\mu \mathrm{m})$ metals such as $\mathrm{Al}, \mathrm{Fe}, \mathrm{Mg}$ and $\mathrm{Zn}$ have all increased during the haze days (B-day and C-night) (Supporting Information Figure S1). For metal Al, Fe and Zn, more emissions were found in the size range of $0.56-1 \mu \mathrm{m}$ during the day than during the night as shown in Figure S1. Particularly, during the haze episodes (B-day and C-night) high Fe levels were detected in 0.32-0.56 $\mu \mathrm{m}$ size range during the night as observed in Figure S1. 
detected during the daytime, especially in the size range of 0.32 to $0.56 \mu \mathrm{m}$ during the haze episode. For the C-Day as referred in Figure 1, the metal As (coal combustion indicator) seemed to have shifted from size of $0.32-0.56 \mu \mathrm{m}$ during the night to the size of 0.56-1 $\mu \mathrm{m}$ during the day. For $\mathrm{Ni}$, even for the clear day (A) higher concentration levels were detected in the size range $0.56-1 \mu \mathrm{m}$, and no elevated levels were detected during the haze episodes, suggesting that $\mathrm{Ni}$ contribution from fugitive dusts or industrial activities might be insignificant for the haze formation studied in this work. For both size ranges $(0.32-0.56 \mu \mathrm{m})$ and $(0.56-1 \mu \mathrm{m})$, metals such as $\mathrm{Mn}, \mathrm{Cu}, \mathrm{Se}, \mathrm{Ba}$ and $\mathrm{Pb}$ were detected to have higher levels than those during the clear day. As can be seen from the figure, during the nighttime higher element Se levels were detected for the C-day (higher $\mathrm{PM}_{2.5}$ levels) in the size range of 0.32 to $0.56 \mu \mathrm{m}$, however during the daytime peak Se levels were found in the size range of $0.56-1 \mu \mathrm{m}$, suggesting Secontaining particles have possibly shifted from smaller sizes to larger sizes. Se is an indicator for coal combustion, and its elevated levels in the particle peak size suggest the coal combustion was one of the driving factors for the haze formation. shown in Figure $1(B)$ and Figure S3. The data in these figures suggest that the elements

244 such as $\mathrm{K}$ might have shifted to different size ranges during the dynamic aerosol 245 processes. Here, we have also studied $\mathrm{SO}_{4}{ }^{3-}, \mathrm{NO}_{3}{ }^{-}$and $\mathrm{NH}_{4}{ }^{+}$concentration levels in the 
concentration levels were all elevated during the high pollution episodes (e.g., the Cday with higher $\mathrm{NO}_{2}$ levels as shown in Figure S2 (Supporting Information)) in contrast to low levels (e.g., the A-day). Literature data show that during a typical haze episode of Beijing sulfate production (Figure $\mathrm{S} 2$ showing a higher $\mathrm{SO}_{2}$ level between 13 and 14, Sept , 2017) is a major contributor to $\mathrm{PM}_{2.5}$ increase(Wang et al., 2016). Here, we also investigated the toxicity of size-resolved PM samples collected from different time periods (daytime and nighttime) and found as shown in Figure 1 (D) that for the size ranges of $0.24-0.74 \mu \mathrm{m}$ the average $\mathrm{PM}_{2.5}$ toxicity (oxidative potential) was higher during the night than during the day though at a lower confidence level ( $p$-value= 0.190), suggesting possible particle composition change during the day. For example,

257 metals such as Fe and As, contributors to PM oxidative potential, in smaller sizes were 258 observed here to have shifted to larger ones. Overall, the observed particle loadings and related chemical compositions here agree with those reported in the literature.

4.2 Massive changes in time-resolved bacterial aerosol concentration and viability in viability for highly polluted days C-night $\left(\mathrm{PM}_{2.5}=108 \mu \mathrm{g} / \mathrm{m}^{3}\right)$ and B-day $\left(\mathrm{PM}_{2.5}=80 \mu \mathrm{g} / \mathrm{m}^{3}\right)$ as shown using viable bacterial percentages in Figure $2(A)$ and Supporting Information

265 (Figure S4, S5). Here, we have simultaneously observed the elevated levels of bacterial growth materials such as ions $\left(\mathrm{NO}_{3}{ }^{-}, \mathrm{NH}_{4}\right.$, etc) as shown in Figure 1 (C) at the same 267 size ranges as discussed above, which co-occurred with increases in bacterial cells and viability as shown in Figure 2 (A). Through fluorescent microscopic analysis of the size- 
resolved PM samples collected using the NanoMoudi as shown in Figure S4, S5

270 (Supporting Information), we have found that the size-resolved bacterial percentages

have varied over the time. For example, as shown in Figure $2(A)$ during the low $\mathrm{PM}_{2.5}$ day (A-day) most of the bacteria were in the larger size ranges (larger than $1 \mu \mathrm{m}$ ) during the nighttime, however during the daytime the peak (about $22 \%$ ) shifted to the size range of 0.56-1 $\mu \mathrm{m}$. Likewise, similar findings were observed for the high $\mathrm{PM}_{2.5}$ day (B) except the percentage was detected to be up to $35 \%$. In contrast, for the high $\mathrm{PM}_{2.5}$ day (C) the peak significantly decreased from $0.56-1 \mu \mathrm{m}$ to larger sizes from the nighttime to daytime. The C-day witnessed a decrease of $\mathrm{PM}_{2.5}$ levels. For both A-Day and C-Day, the total bacteria have decreased from nighttime to daytime, however for the B-day the total bacteria increased from nighttime to daytime. In addition to microscopic analysis, we have also performed qPCR analysis for the size-resolved bacterial aerosol samples as shown in Figure S6 (Supporting Information). Overall, the qPCR data agreed well with the microscopic data (Supporting Information Figure S4). The total bacteria seemed to have decreased from nighttime to daytime, however for a particular size range, e.g., $0.56-1 \mu \mathrm{m}$, their percentages have increased from nighttime to daytime. Overall, these data revealed that bacterial levels in the size ranges of 0.56-1 $\mu \mathrm{m}$ have changed from nighttime to daytime, implying a changing bacterial aerosol dynamic under different time and pollution conditions.

Using BackLight DNA stain method, $50-70 \%$ of viable bacteria were found in the size range of $0.56-1 \mu \mathrm{m}$ as observed in Figure 2 (B) and Figure S4, S5 for the A-day and B-day (haze formation day) during the daytime, while less than $20 \%$ of viable bacteria 

peak for viable bacteria about $30 \%$ was found at $0.32-0.56 \mu \mathrm{m}$ for B-night, close to $60 \%$

294 found at the $0.56-1 \mu \mathrm{m}$ for C-night and about $10 \%$ for the A-night (Supporting Information Figure S5). The size-resolved percentages of viable bacteria for three different days (A- "biomass burning" day, B-"haze formation"day, C-"haze disappearing" day) were observed to have changed substantially (Supporting Information Figure S5). For dead bacteria, as shown in the figure, in the size range of $0.56-1 \mu \mathrm{m}$, higher percentage was observed for the C-day, and the lowest for the B-day (the haze formation day) during the nighttime. However, for the daytime, the highest percentage was observed in the size range of 5.6-10 $\mu \mathrm{m}$ for the C-day (haze disappearing day). The percentages for the A- and B-day were found to be similar as seen in the figure. In this work, we have also analyzed the endotoxin (a bacterial derivative) levels during the Information Figure S7. As shown in the figure, for the A- and B-day most of the endotoxin was detected in the smaller size ranges of $0.032-0.18 \mu \mathrm{m}$, while during the daytime most of the endotoxin was detected in the larger sizes of $>3.2 \mu \mathrm{m}$. In this work, we have also observed that the endotoxin levels for those hazy days (B and C) were found to be higher than the clear day $(A)$ with lower $\mathrm{PM}_{2.5}$ levels for 1-18 $\mu \mathrm{m}$ size range ( $p$-value $=0.023$ ), although no statistically significant differences were detected between daytime and nighttime. In a previous work, Wei et al. also reported that 
314 including the microscopic data (size-resolved percentages of viable bacteria, qPCR, viability and endotoxin, total bacteria) together with favorable bacterial growth conditions suggest that bacteria in the size range of $0.56-1 \mu \mathrm{m}$ could have played a non-neglected role for air pollution episodes.

To further understand the problem with bacteria in highly polluted air, we have conducted another three different sets of experiments on May 12-13, 2018, March 1012, 2018, and Feb 6-7, 2018. Different from the first NanoMoudi experiment, we took time-resolved air samples (20 $\mathrm{m}^{3}$ air for $20 \mathrm{~min}$ ) using a high-volume sampler (HighBioTrap, dBlueTech Co., Ltd, Beijing China) every two hours for different time periods to capture the bacterial growth events. As seen from Figure $2(A, B, C)$, at 16:00 of May 12 with a $\mathrm{PM}_{2.5}$ level up to $160 \mu \mathrm{g} / \mathrm{m}^{3}$, we have detected a significantly higher bacterial aerosol concentration using $\mathrm{qPCR}$, which also corresponded to higher viable bacterial levels $\left(53,037\right.$ cells $\left./ \mathrm{m}^{3}\right)$ as detected using DNA stain (Figure $2(\mathrm{C})$ ). For other time periods, the bacterial aerosol concentration levels were detected to decrease substantially (2 hours after the high PM episode) as shown in Figure 2 (B) down to 1689 cells $/ \mathrm{m}^{3}$ as shown in Figure 2 (A) by qPCR; Figure 2 (B) and Figure 2 (E) by DNA stain, respectively for different $\mathrm{PM}_{2.5}$ levels. Figure 2 (F) shows the culturable bacteria for $1.33 \mathrm{~m}^{3}$ air sampled during different $\mathrm{PM}_{2.5}$ levels, and the results were comparable to those detected using DNA stain method as shown in Figure 2 (C), Figure 2 (D) and 
viable bioaerosol particle concentration increased over a 6-fold at night or early dawn during the haze episode compared with that on clean day(Wei et al., 2016). Culturable bacteria concentrations during the haze days were also observed to be higher than those during the non-haze days(Li et al., 2015). In another work aerosolized bacteria were shown to experience metabolic activity in the simulated air state when supplied with carbon source (Krumins et al., 2014). However, Amato et al. reported that after the $18 \mathrm{~h}$ aerosolization of the bacteria into the air its cultivable bacterial percentage if without adding nutrients started to decrease down to 4\% (Amato et al., 2015). Our data from qPCR, DNA stain, and culturing in these sets of experiments as illustrated in

Figure 2 further reveal that massive changes in time-resolved bacterial aerosol dynamics are taking place in highly polluted air, e.g., during haze episodes in Beijing.

\subsection{Massive time-resolved bacterial community structure shifts in highly polluted air}

To further investigate the specific bacterial species that have experienced the massive changes in the polluted air, the collected air samples were sequenced and also analyzed using ion chromatography methods (both VITEK MS and Microflex). Here, we have found as shown in Figure $3(A)$ that during clear days (14 to $93 \mu \mathrm{g} / \mathrm{m}^{3}$ ) as a control on Feb 6-7, 2018 regardless of the sampling time periods, the bacterial structures

354 remained to be relatively uniform for most of the studied time. Nonetheless, we have 355 still detected a difference in bacterial structures as seen in Figure $3(A)$ for the time of 356 20:00PM on Feb 6, 2018, showing an increase in abundances of Ralstonia and 
$75 \mu \mathrm{g} / \mathrm{m}^{3}$. For the clear day, among those bacterial genera detected, Ralstonia and

Acinetobacter were found to be most abundant. Besides, Psychrobacter and Massilia

were also detected among the top 20 genera. In contrast, as shown in Figure 3 (B) the

bacterial structures varied greatly within a day during the haze days $\left(\mathrm{PM}_{2.5}\right.$ level up to

$251 \mathrm{\mu g} / \mathrm{m}^{3}$ ) on March 10-12, 2018. Among the bacterial genera detected,

Psychrobacter, Massilia, Acinetobacter, and Arthrobacter were found to dominate the

community structure. During low level of air pollution episodes as shown in Figure 3

(A), Ralstonia was detected to be the second dominant species up to $4.16-14.66 \%$,

however during high pollution episodes $\left(\mathrm{PM}_{2.5}\right.$ concentration up to $\left.251 \mu \mathrm{g} / \mathrm{m}^{3}\right)$,

Ralstonia was found to only account for $0-0.78 \%$ of the total abundances, a substantial

13), as observed in Figure 3 (B) when the $\mathrm{PM}_{2.5}$ levels increased the relative shown in Figure 3 (C) for March 10-12, 2018.

To further investigate the problem and confirm these findings, we have conducted another set of different experiments on May 12, 2018 using similar methods. In contrast to other experiments, culturable Acinetobacter Iwoffii, Bacillus cereus, 
methods including VITKE MS (BioMérieux) and microflex (Bruker) (two methods confirmed with each other for specific species) as seen in Figure 3 (D) and Figure 3 (E). Among these species, Acinetobacter Iwoffii, Exiguobacterium aurantiacum, and Bacillus pumilus were found to be most abundant. Bacillus pumilus and

Exiguobacterium aurantiacum are often used in wastewater treatment practices,

while Acinetobacter Iwoffii is a human pathogen. The differences observed in bacterial aerosol dynamics in different PM pollution episodes indicate that air pollution episodes could varied from one to another in their characteristics. For low and high PM pollution levels, the bacterial aerosol dynamics appeared to be very different. For low level PM pollution, the bacterial aerosol structures remained to be relatively constant, in contrast bacterial structures experienced rapid changes during the day not only in abundances but also in species, e.g., several species such as Psychrobacter could account for more than $90 \%$ of the total abundance as shown in Figure 3 (B). Among the detected species, Psychrobacter is a psychrophilic bacterium and used in wastewater treatment(Huang et al., 2018), while Massilia is also used in degrading water-borne PAH(Chadhain et al., 2006). The results obtained in this repeated experiment on a different haze day further strengthen the fact that rapid and timeresolved massive changes in bacterial aerosol dynamics have taken place for different $\mathrm{PM}_{2.5}$ pollution levels. 
were observed, which co-occurred with significant bacterial aerosol species shift

403 (Acinetobacter increased significantly) as observed in Figure $3(\mathrm{~A})$. The Ca ion level was

404 observed more than $0.55 \mu \mathrm{g} / \mathrm{m}^{3}$, followed by $\mathrm{Na}, \mathrm{Mg}, \mathrm{K}$ and others as shown in Figure

4054 (A). These element ions are necessary for bacterial growth. Likewise, for March 10-

40613 experiments, several different ion peaks were observed as shown in Figure 4 (B).

407 For those samples collected at 20:00PM of March 11 ("11-20" in the figure) and

408 08:00AM of March 12 ("12-8" in the figure), elevated $\mathrm{Ca}, \mathrm{Na}$ and $\mathrm{Mg}$ levels were also

409 observed up to $0.9 \mu \mathrm{g} / \mathrm{m}^{3}$ for Ca ion, corresponding to significant bacterial aerosol

410 shifts as observed in Figure $3(B)$. It seems that as observed in Figure 3 (B) and Figure

4 (B) Acinetobacter and Massilia alternated to dominate the bacterial aerosol

community structures. When Ca ion level increased Acinetobacter started to dominate,

while $\mathrm{Na}$ level increased Massilia started to dominate. The co-occurrence of time-

resolved element ion elevation with time-resolved bacterial aerosol structure shift

suggest the ions must have been to some extent related to bacterial aerosol dynamics

in the air. In addition, we have also constructed a HYSPLIT Trajectory Model for air mass

5 along the transport directions most of $\mathrm{PM}_{2.5}$ levels were below $100 \mathrm{\mu g} / \mathrm{m}^{3}$.

421 Accordingly, it is hard to believe that regional air mass transport contributed directly 


\subsection{A new frame for understanding air pollution episodes}

Air pollution has resulted in tremendous loss of life and economy every year worldwide. Huge amount of research has already been devoted to studying the haze formation and the aerosol chemistry mechanisms(Wang et al., 2006;Zhao et al., 2013; Liu et al., 2013). However, microbial aerosols rarely been considered to play a role in aerosol chemistry especially in highly polluted air. Previously, we have shown using a laser-induced fluorescence-based method that the viable bacterial aerosol concentration was significantly elevated during high $\mathrm{PM}_{2.5}$ pollution episodes in Beijing(Wei et al., 2016). Here, for the first time we have captured the size-and timeresolved massive microbial level increase and structure shift events in high $\mathrm{PM}_{2.5}$ polluted air in Beijing using a high-volume portable aerosol sampler up to $1000 \mathrm{~L} / \mathrm{min}$. Traditionally, people often use low flow rate sampler such as BioSampler (SKC, INc., flow rate $=12.5 \mathrm{~L} / \mathrm{min})$ and the 4-channel PM sampler $(16.7 \mathrm{~L} / \mathrm{min})$ or sometimes up to $100 \mathrm{~L} / \mathrm{min}$, but most for short time samplings(Gao et al., 2015b;Yuan et al., 2017). These samplers with low sampling rates often fail to capture rapid but transient microbial events in the air since newly bacterial aerosol dynamics could be quickly diluted by open ambient air, and such time-resolved events could also discontinue as atmospheric conditions change from the air. For example, through NMDS analysis we detected a difference in bacterial community structures in the samples collected by the HighBioTrap sampler, but not those collected using the 4-Channel PM sampler (16.7 L/min) as shown in Figure S9 (Supporting Information). Here, by applying a high volume sampler we were able to successfully capture the time-resolved changes in 
microbial aerosol dynamics in the air.

Accordingly, based on the results obtained here we hypothesize a new haze formation mechanism, i.e., some new aerosol chemistry for highly polluted air as illustrated in Figure 6. As depicted from the figure, bacteria are presumed to be emitted from ground due to various human activities into the air. As such an evidence 452 shown in Figure S10, we found that the bacterial aerosol concentration level exceeded $3000 \mathrm{CFU} / \mathrm{m}^{3}$ in a pharmaceutical plant in China. In addition, sequence data shown in

455 Exiguobacterium, and Bacillus genera were emitted and detected to dominate 456 airborne bacterial community in workshop air inside the pharmaceutical plant. As 457 discussed, these bacteria were also detected in the ambient air in Beijing during the 458 haze episodes, and some of these bacteria experienced rapid concentration changes 459 in the air as presented in Figure 3. Besides, the total VOC concentration for one 460 chimney (pharmaceutical waste treatment workshop) inside the plant was observed to reach a level of 15,030 ppbv, which mainly consisted Acetone (61\%) and 462 Acetaldehyde (11\%) as seen in Figure S12(Supporting Information). These data support 463 our claim that ground human activities such as pharmacy producing could emit large 464 amounts of bacteria into the air, which were also detected in highly polluted air. As 465 detected in the air samples in this work, the nutrients for bacterial growth such as $\mathrm{NH}_{4}{ }^{+}$, $466 \mathrm{NO}_{3}{ }^{-}, \mathrm{Ca}, \mathrm{Na}, \mathrm{K}, \mathrm{Mg}$, etc. along with other favorable conditions such as $\mathrm{RH}$ and gases 467 are readily available in highly polluted atmosphere such as haze episodes in Beijing, 

hypothesize that the bacterial growth in the air could have taken place during air pollution episodes as depicted in Figure 6 . The bacterial growth typically can undergo

471 for different cycles (in general 20-30 min per cycle), depending on the availability of 472 various conditions such as nutrients, $\mathrm{RH}$ and temperature. As hypothesized in Figure 6, for typical high PM pollution episodes, atmospheric boundary layer is lowered(Quan et al., 2014), thus leading to increases in ambient pollutant concentrations such as VOC, $\mathrm{NH}_{3}, \mathrm{NOx}$, etc. Under these conditions, the airborne bacteria such as Acinetobacter Iwoffii, Bacillus cereus, Bacillus pumilus, Exiguobacterium aurantiacum, Arthrobacter ilicis, Bacillus cereus, Bacillus megaterium, Coriobacterium emitted from ground 478 human activities, e.g., as demonstrated from a pharmaceutical or a wastewater 479 treatment plant, as hypothesized in Figure 6 can play an important role for 480 atmospheric carbon and nitrogen cycles during their growth, thus influencing aerosol 481 chemistry. 1998; Krumins et al., 2014), degrade PAH(Chadhain et al., 2006), oxidize NOx(Lambeth, 2004) and scavenge OH radicals(Samake et al., 2017), and at the same time bacteria 486 can also release many mVOCs during their growth(Schulz and Dickschat, 2007). 487 According to the literature, these mVOCs are often small molecular weight molecules 488 (<300 Da) such as hydrocarbons, alcohols, aldehydes and ketones), terpenoids, 489 aromatic compounds, nitrogen containing compounds and volatile sulphur 
fluorescens can emit low volatility Methylsulfonylsulfanylmethane $\left(\mathrm{C}_{2} \mathrm{H}_{6} \mathrm{O}_{2} \mathrm{~S}_{2}\right.$, LogP= -

Acinetobacter during higher PM pollution episodes. On the other hand, Ralstonia solanacearum can emit nitrogen containing compounds such as 2-chloro-2nitropropane $\left(\mathrm{C}_{3} \mathrm{H}_{6} \mathrm{CINO}_{2}\right)$ (Spraker et al., 2014). In our work, we have detected higher abundance of Ralstonia species in our work as shown in Figure $3 \mathrm{~A}$ ). In another work, it was shown that Psychrobacter spp. can emit 2,3-Dimethyl-oxirane, 2-Butanone, 2-

500 Formylhistamine, 2-Methyl-2-propanol, Acetaldehyde, Acetone, Ethylene oxide, 501 Isopropylalcohol, and Trimethylamine(Broekaert et al., 2013). For a complete reference to $\mathrm{mVOC}$ emitted by both bacteria and fungi, there is a database available in the literature(Lemfack et al., 2013). As seen from the database, bacteria, depending

504 on the species type, could emit mVOCs containing sulfur, nitrogen or simply hydrocarbon ${ }^{35}$. These smaller molecules (mVOCs) can be further oxidized into ultrafine particles under oxidizing environments, and some of them are sVOC with lower vapor pressure.

These analyses led to our belief that the bacterial growth, accordingly emitting mVOCs as new particle precursors, in the air could play a very important role for new 
new particle formation occurred during the early mornings (04:00-06:00) or during the afternoon time period (18:00-22:00) (Liu et al., 2008;Wang et al., 2014). During these same time periods, massive changes in bacterial aerosol levels and structure shifts were also observed in our work as shown in Figure 1-3. As illustrated in Figure 6, these ultrafine particles eventually could grow into fine particles via hydroscopic growth or through atmospheric oxidization(Guo et al., 2014). Depending on the bacterial species or the ambient pollutants, major components of the sVOC ultrafine particles emitted if any in the air as hypothesized could be organic compounds, nitrogen containing or sulfates, thus likely impacting haze episode dynamics. Simultaneously, airborne bacteria can also scavenge $\mathrm{OH}$ radicals(Samake et al., 2017) and react with metals such as Fe(Chen et al., 2013) in the water layer as depicted in Figure 6. During a certain time period, the available nutrients for bacteria are depleting in the atmosphere, then the bacterial growth may slow down and eventually stop. From our observations, these bacteria are mostly in the size range $0.5-1 \mu \mathrm{m}$, and those newly produced ones can be quickly attached by atmospheric ultrafine particles or form aggregates, which could later grow into bigger particles and settle to the ground. When the latter occurs, the high PM pollution episode is disappearing. Here, some psychrophilic bacteria were also detected, indicating microbial growth in the cold air could also occur, e.g., during the winter periods when frequent hazes occur. Those bacteria trained for engineering purposes can also significantly impact human health and ecology when they have undergone growth if any in the air and further precipitated into the local environments or inhaled by humans during high air pollution episodes. For example, we have 
detected abundant human pathogen such as Acinetobacter Iwoffii in highly polluted air, which thus presents a significant public health concern. The hypothesized bacterial growth in the air partly could explain the underestimates (e.g. HCHO was underestimated by about $16 \%$ compared to observation) of atmospheric VOCs by current models, and also the under-prediction (about 30\%) of $\mathrm{OH}$ radical loss rate $(\mathrm{OH}$ radicals react with VOCs)(Whalley et al., 2016). Here, we only investigated the bacterial dynamics, while those airborne fungal species could also have an impact in the air under favorable conditions. This work was mainly conducted in Beijing, and certainly many other urban settings are warranted to further verify the findings from this work.

544 known so far especially in highly polluted air. The relevant results might find their

545 values in future cost-effective air pollution control practices. The hypothesized

546 airborne bacterial growth mechanism can be explored using an isotope-based experimental method in future studies.

\section{Acknowledgements}


MY designed the study, TZ performed the experiments, $\mathrm{XL}, \mathrm{MW}$ helped conducting some of the samplings, $\mathrm{XL}, \mathrm{HC}$ collected the air samples from the pharmaceutical plant. TZ and MY prepared the manuscript with contributions from all co-authors. The results here only represent scientific evidences and the authors' understanding of the problem.

\section{References}

562 Amato, P., Joly, M., Schaupp, C., Attard, E., Möhler, O., Morris, C., Brunet, Y., and Delort, A.-M.: Survival and ice nucleation activity of bacteria as aerosols in a cloud simulation chamber, Atmospheric Chemistry and Physics, 15, 6455-6465, doi:10.5194/acp-156455-2015, 2015.

Behera, S. N., Betha, R., Huang, X., and Balasubramanian, R.: Characterization and estimation of human airway deposition of size-resolved particulate-bound trace elements during a recent haze episode in Southeast Asia, Environmental Science and Pollution Research, 22, 4265-4280, doi:10.1007/s11356-014-3645-6, 2015.

570 Broekaert, K., Noseda, B., Heyndrickx, M., Vlaemynck, G., and Devlieghere, F.: Volatile

571 compounds associated with Psychrobacter spp. and Pseudoalteromonas spp., the

572 dominant microbiota of brown shrimp (Crangon crangon) during aerobic storage,

573 International Journal of Food Microbiology, 166, 487-493, 574 doi:10.1016/i.ijfoodmicro.2013.08.013, 2013.

575 Cao, C., Jiang, W., Wang, B., Fang, J., Lang, J., Tian, G., Jiang, J., and Zhu, T. F.: Inhalable 576 microorganisms in Beijing's PM2. 5 and PM10 pollutants during a severe smog event,

577 Environmental Science \& Technology, 48, 1499-1507, doi:10.1021/es4048472, 2014. 

dioxygenase gene population shifts during polycyclic aromatic hydrocarbon biodegradation, Applied and Environmental Microbiology, 72, 4078-4087, doi: 10.1128/AEM.02969-05, 2006. rapid microbial detection, Journal of Aerosol Science, 117, 212-223, doi: 10.1016/j.jaerosci.2017.11.012, 2018.

Chen, Q., Li, J., Wu, Y., Shen, F., and Yao, M.: Biological responses of Gram-positive and doi: 10.1039/C3RA40570B, 2013.

588 Fröhlich-Nowoisky, J., Kampf, C. J., Weber, B., Huffman, J. A., Pöhlker, C., Andreae, M. O., Lang-Yona, N., Burrows, S. M., Gunthe, S. S., and Elbert, W.: Bioaerosols in the Earth system: Climate, health, and ecosystem interactions, Atmospheric Research, 182, $346-$ 376, doi: 10.1016/j.atmosres.2016.07.018, 2016.

Gao, J.-F., Fan, X.-Y., Pan, K.-L., Li, H.-Y., and Sun, L.-X.: Diversity, abundance and activity of ammonia-oxidizing microorganisms in fine particulate matter, Scientific Reports, 6 , 38785, doi: 10.1038/srep38785, 2016.

Gao, M., Jia, R., Qiu, T., Han, M., Song, Y., and Wang, X.: Seasonal size distribution of 596 airborne culturable bacteria and fungi and preliminary estimation of their deposition 597 in human lungs during non-haze and haze days, Atmospheric Environment, 118, 203210, doi: 10.1016/j.atmosenv.2015.08.004, 2015a.

599 Gao, M., Qiu, T., Jia, R., Han, M., Song, Y., and Wang, X.: Concentration and size 
distribution of viable bioaerosols during non-haze and haze days in Beijing, Environmental Science and Pollution Research, 22, 4359-4368, doi: 10.1007/s11356014-3675-0, 2015b.

Guo, S., Hu, M., Zamora, M. L., Peng, J., Shang, D., Zheng, J., Du, Z., Wu, Z., Shao, M., and Zeng, L.: Elucidating severe urban haze formation in China, Proceedings of the National Academy of Sciences, 111, 17373-17378, doi: 10.1073/pnas.1419604111, 2014.

Huang, X., Ding, A., Liu, L., Liu, Q., Ding, K., Niu, X., Nie, W., Xu, Z., Chi, X., and Wang, M.: Effects of aerosol-radiation interaction on precipitation during biomass-burning season in East China, Atmospheric Chemistry \& Physics, 16, 10063-10082, doi:10.5194/acp-16-10063-2016, 2016.

Huang, Z., Wang, Y., Jiang, L., Xu, B., Wang, Y., Zhao, H., and Zhou, W.: Mechanism and performance of a self-flocculating marine bacterium in saline wastewater treatment, Chemical Engineering Journal, 334, 732-740, doi: 10.1016/j.cej.2017.10.076, 2018.

Hunziker, L., Bönisch, D., Groenhagen, U., Bailly, A., Schulz, S., and Weisskopf, L.: Pseudomonas strains naturally associated with potato plants produce volatiles with high inhibition potential against Phytophthora infestans, Applied and Environmental Microbiology, 8,821-830, doi: 10.1128/AEM.02999-14, 2015.

Jing, H., Li, Y.-F., Zhao, J., Li, B., Sun, J., Chen, R., Gao, Y., and Chen, C.: Wide-range particle characterization and elemental concentration in Beijing aerosol during the 2013 Spring Festival, Environmental Pollution, 192, 204-211, doi: 10.1016/j.envpol.2014.06.003, 2014. 
Jokinen, T., Berndt, T., Makkonen, R., Kerminen, V.-M., Junninen, H., Paasonen, P., Stratmann, F., Herrmann, H., Guenther, A. B., and Worsnop, D. R.: Production of extremely low volatile organic compounds from biogenic emissions: Measured yields and atmospheric implications, Proceedings of the National Academy of Sciences, 11,7123-7128, doi: 10.1073/pnas.1423977112, 2015.

Krumins, V., Mainelis, G., Kerkhof, L. J., and Fennell, D. E.: Substrate-dependent rRNA production in an airborne bacterium, Environmental Science \& Technology Letters, 1, 376-381, doi: 10.1021/ez500245y, 2014.

Lambeth, J. D.: NOX enzymes and the biology of reactive oxygen, Nature Reviews Immunology, 4, 181-189, doi: 10.1038/nri1312, 2004.

Lemfack, M. C., Nickel, J., Dunkel, M., Preissner, R., and Piechulla, B.: mVOC: a database of microbial volatiles, Nucleic Acids Research, 42, D744-D748, doi: 10.1093/nar/gkt1250 2013.

Li, Y., Fu, H., Wang, W., Liu, J., Meng, Q., and Wang, W.: Characteristics of bacterial and fungal aerosols during the autumn haze days in Xi'an, China, Atmospheric Environment, 122, 439-447, doi: 10.1016/j.atmosenv.2015.09.070, 2015.

Liu, H., Zhang, X., Zhang, H., Yao, X., Zhou, M., Wang, J., He, Z., Zhang, H., Lou, L., and Mao, W.: Effect of air pollution on the total bacteria and pathogenic bacteria in different sizes of particulate matter, Environmental Pollution, 233, 483-493, doi: 10.1016/j.envpol.2017.10.070, 2018.

Liu, S., Hu, M., Wu, Z., Wehner, B., Wiedensohler, A., and Cheng, Y.: Aerosol number size distribution and new particle formation at a rural/coastal site in Pearl River Delta 
644 (PRD) of China, Atmospheric Environment, 42, 6275-6283, doi: 645 10.1016/j.atmosenv.2008.01.063, 2008.

646 Liu, X., Li, J., Qu, Y., Han, T., Hou, L., Gu, J., Chen, C., Yang, Y., Liu, X., and Yang, T.:

647 Formation and evolution mechanism of regional haze: a case study in the megacity

648 Beijing, China, Atmospheric Chemistry \& Physics, 12, 16259-16292, doi:10.5194/acp649 13-4501-2013, 2013.

650 Paavolainen, L., Kitunen, V., and Smolander, A.: Inhibition of nitrification in forest soil 651 by monoterpenes, Plant and Soil, 205, 147-154, doi: 10.1023/A:100433541, 1998.

652 Pöschl, U., Martin, S., Sinha, B., Chen, Q., Gunthe, S., Huffman, J., Borrmann, S., Farmer, 653 D., Garland, R., and Helas, G.: Rainforest aerosols as biogenic nuclei of clouds and 654 precipitation in the Amazon, Science, 329, 1513-1516, doi: 10.1126/science.1191056, 6552010.

656 Price, P. B., and Sowers, T.: Temperature dependence of metabolic rates for microbial 657 growth, maintenance, and survival, Proceedings of the National Academy of Sciences, 658 101, 4631-4636, doi: 10.1073/pnas.0400522101, 2004.

659 Quan, J., Tie, X., Zhang, Q., Liu, Q., Li, X., Gao, Y., and Zhao, D.: Characteristics of heavy 660 aerosol pollution during the 2012-2013 winter in Beijing, China, Atmospheric 661 Environment, 88, 83-89, doi: 10.1016/j.atmosenv.2014.01.058, 2014.

662 Samake, A., Uzu, G., Martins, J., Calas, A., Vince, E., Parat, S., and Jaffrezo, J.: The 663 unexpected role of bioaerosols in the Oxidative Potential of PM, Scientific Reports, 7, 664 10978, doi: 10.1038/s41598-017-11178-0, 2017.

665 Š antl-Temkiv, T., Sahyoun, M., Finster, K., Hartmann, S., Augustin-Bauditz, S., 
Environment, 109, 105-117, doi: 10.1016/j.atmosenv.2015.02.060, 2015.

Schulz, S., and Dickschat, J. S.: Bacterial volatiles: the smell of small organisms, Natural

Tsai, J.-H., Lin, J.-H., Yao, Y.-C., and Chiang, H.-L.: Size distribution and water soluble

680 ions of ambient particulate matter on episode and non-episode days in Southern

681 Taiwan, Aerosol and Air Quality Research, 12, 263-274, doi:

S., and Meng, J.: Persistent sulfate formation from London Fog to Chinese haze, 
688

aerosols at Mt. Huang and Nanjing in the Yangtze River Delta, China: Effects of air masses and characteristics of new particle formation, Atmospheric Research, 150, 4256, doi: 10.1016/j.atmosres.2014.07.020, 2014.

Wang, Y., Zhuang, G., Sun, Y., and An, Z.: The variation of characteristics and formation mechanisms of aerosols in dust, haze, and clear days in Beijing, Atmospheric Environment, 40, 6579-6591, doi: 10.1016/j.atmosenv.2006.05.066, 2006.

Wei, K., Zou, Z., Zheng, Y., Li, J., Shen, F., Wu, C.-y., Wu, Y., Hu, M., and Yao, M.: Ambient bioaerosol particle dynamics observed during haze and sunny days in Beijing, Science of the Total Environment, 550, 751-759, doi: 10.1016/j.scitotenv.2016.01.137, 2016.

Whalley, L., Stone, D., Bandy, B., Dunmore, R., Hamilton, J. F., Hopkins, J., Lee, J. D., Lewis, A. C., and Heard, D. E.: Atmospheric $\mathrm{OH}$ reactivity in central London: observations, model predictions and estimates of in situ ozone production, Atmospheric Chemistry and Physics, 16, 2109-2122, doi: 10.5194/acp-16-2109-2016, 2016.

Yuan, H., Zhang, D., Shi, Y., Li, B., Yang, J., Yu, X., Chen, N., and Kakikawa, M.: Cell concentration, viability and culture composition of airborne bacteria during a dust event in Beijing, Journal of Environmental Sciences, 55, 33-40, doi: 10.1016/j.jes.2016.03.033, 2017.

Yue, Y., Chen, H., Setyan, A., Elser, M., Dietrich, M., Li, J., Zhang, T., Zhang, X., Zheng, Y., Wang, J., and Yao, M.: Size-resolved endotoxin and oxidative potential of ambient particles in Beijing and Zürich, Environmental Science \& Technology, 52 , 6816-6824, doi: 10.1021/acs.est.8b01167, 2018. 
(A) 1

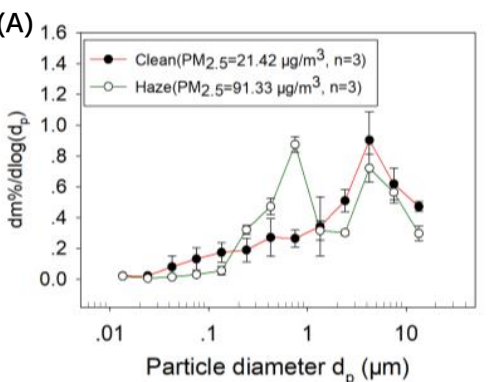

(C)
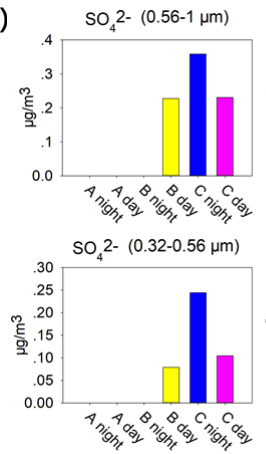

(B)

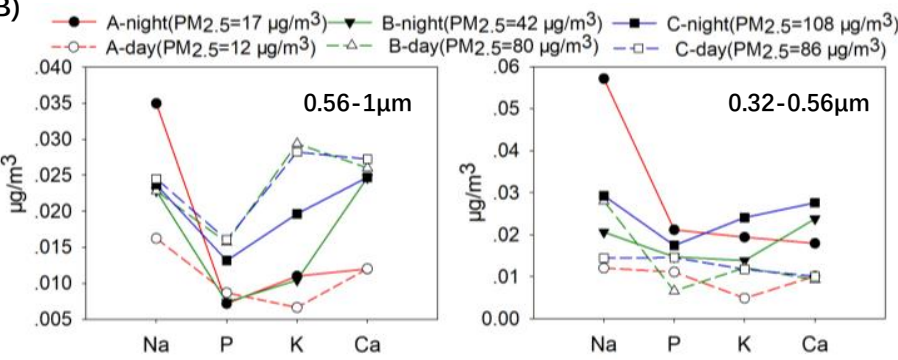

$\mathrm{NH}^{+}+(0.56-1 \mu \mathrm{m})$

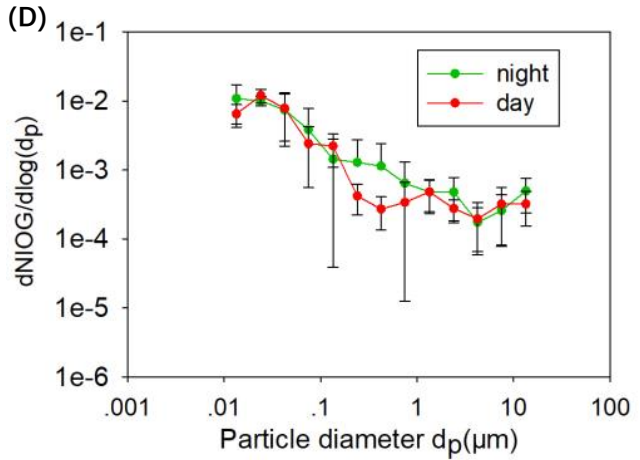

Figure 1 Rapid particle increase during typical high PM pollution episodes on Sept 11-

14, 2017: A) size-resolved particle mass percentage distribution during low (21.42 $\left.\mu \mathrm{g} / \mathrm{m}^{3}\right)$ and high $\left(91.33 \mu \mathrm{g} / \mathrm{m}^{3}\right)$ pollution levels $\left(\mathrm{PM}_{2.5}\right.$ values are averages of three different days (Sept 11-14, 2017); B) Na, P, K, Ca concentration levels in particles of

Night: 20:00PM-6:00AM on Sept 11-14, 2017) under different PM pollution levels 
725 (Corresponding $\mathrm{O}_{3}, \mathrm{NO}_{2}, \mathrm{SO}_{2}, \mathrm{CO}$ concentration levels are shown in Supporting

726 Information Figure S2) ; D) Size-resolved (10 nm-20 $\mu \mathrm{m})$ particle toxicity measured using DTT method during night and day as shown in Figure 1 (B). Air samples were collected using the NanoMoudi sampler at a flow rate of $28 \mathrm{~L} / \mathrm{min}$ for 12 hours during

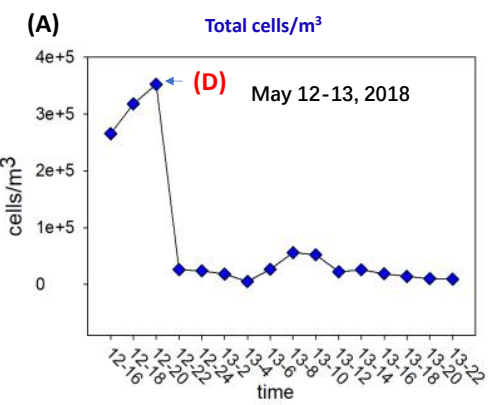

(D) May 12, 20: 00-20: 40, $\mathrm{PM}_{2.5}=37 \mu \mathrm{g} / \mathrm{m}^{3} \quad$ (E)

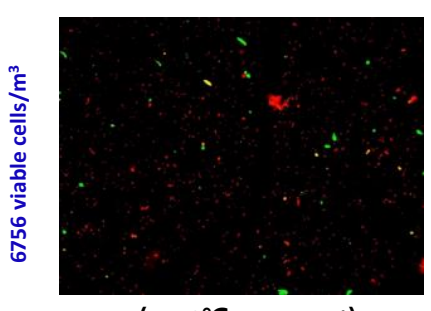

$\left(\mathrm{T}=19^{\circ} \mathrm{C}, \mathrm{RH}=54 \%\right)$
(B)

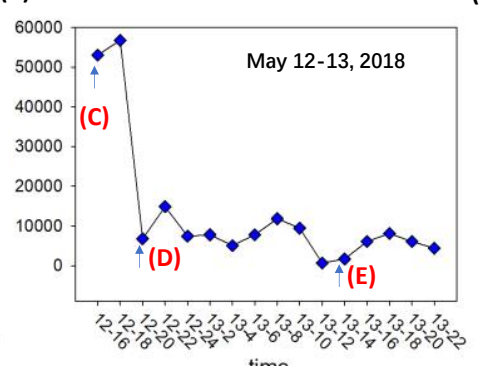

E) May 13, 14: 00-14: 40, $\mathrm{PM}_{2.5}=45 \mu \mathrm{g} / \mathrm{m}^{3}$

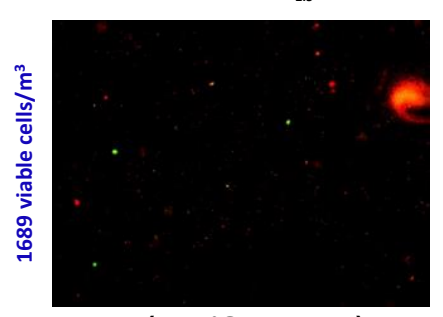

$\left(\mathrm{T}=26^{\circ} \mathrm{C}, \mathrm{RH}=39 \%\right)$
(C) May 12, 16: 00-16: 40, $\mathrm{PM}_{2.5}=160 \mu \mathrm{g} / \mathrm{m}^{3}$

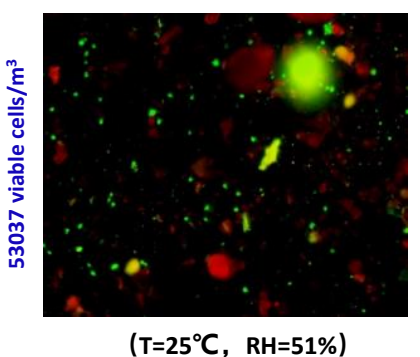

(F)

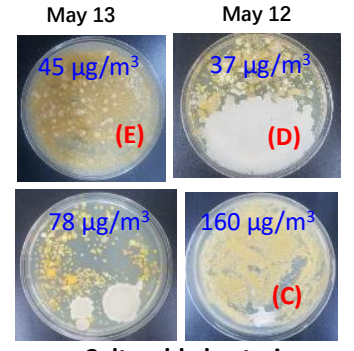

Figure 2 Time-resolved bacterial aerosol dynamics in highly polluted air: A) Total

bacterial aerosol concentration levels detected at different times on May 12-13, 2018

using qPCR; B) Total viable bacterial aerosol particle concentration measured using

BackLight DNA stain method for different time periods (the digit separated by "-

“ represent date and time, respectively, e.g., “12-22” means 22:00PM on May 12)

during May 12-13, 2018 under different air pollution levels $\left(37-160 \mu \mathrm{g} / \mathrm{m}^{3}\right)\left(\mathrm{PM}_{2.5}\right.$ 
741 during a high $\mathrm{PM}_{2.5}$ pollution episode $\left(\mathrm{PM}_{2.5}=160 \mu \mathrm{g} / \mathrm{m}^{3}\right.$ at $20: 00-20: 40$ on May 12 ,

742 2018); D) Example image of bacterial DNA stain results from air samples collected

743 during a low level $\mathrm{PM}_{2.5}$ pollution episode $\left(\mathrm{PM}_{2.5}=37 \mu \mathrm{g} / \mathrm{m}^{3}\right.$ at 16:00-16:40 on May 12,

744 2018); E) Bacterial DNA stain results from air samples collected during a medium level

$745 \mathrm{PM}_{2.5}$ pollution episode ( $\mathrm{PM}_{2.5}=45 \mu \mathrm{g} / \mathrm{m}^{3}$ at $14: 00-14: 40$ on May 13,2018$) ; \mathrm{F}$ ) Example

746 images of bacterial aerosol culturing agar plates $\left(1.33 \mathrm{~m}^{3}\right.$ air collected using the

747 HighBioTrap) under different PM2.5 mass levels during May 12-13, 2018.
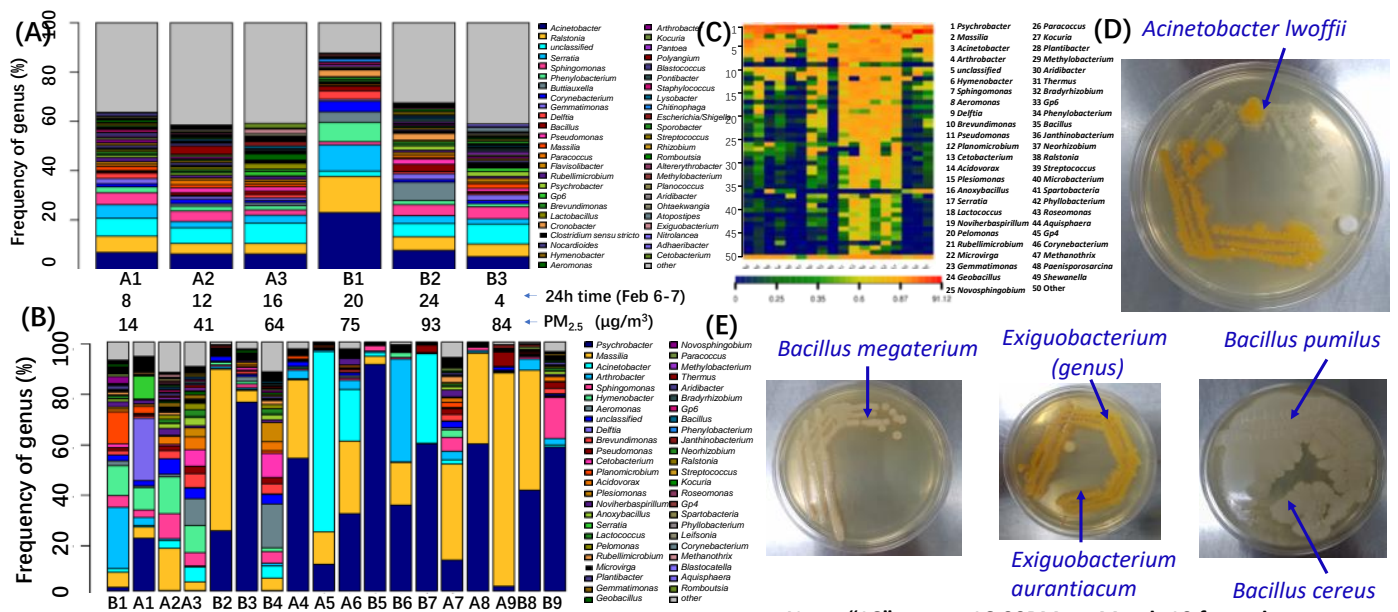

B1 A1 A2A3 B2 B3 B4 A4 A5 A6 B5 B6 B7 A7 A8 A9B8 B9 G coobacius (March 10-13) Note: “16" means 16:00PM on March 10 from the most

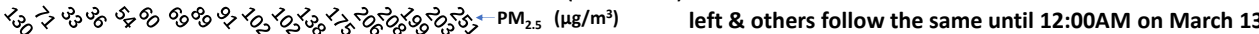

Figure 3 Dynamics of bacterial community structures for different time periods during 
758 (BioMérieux) and microflex (Bruker) for their corresponding bacterial species;

759 Acinetobacter Iwoffii and Exiguobacterium aurantiacum were found to be most

760 abundant.

761

762

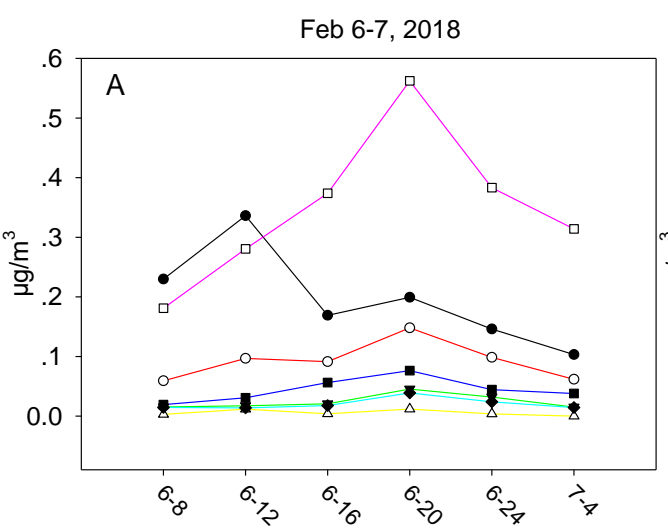

Sampling time(Day-Hour)

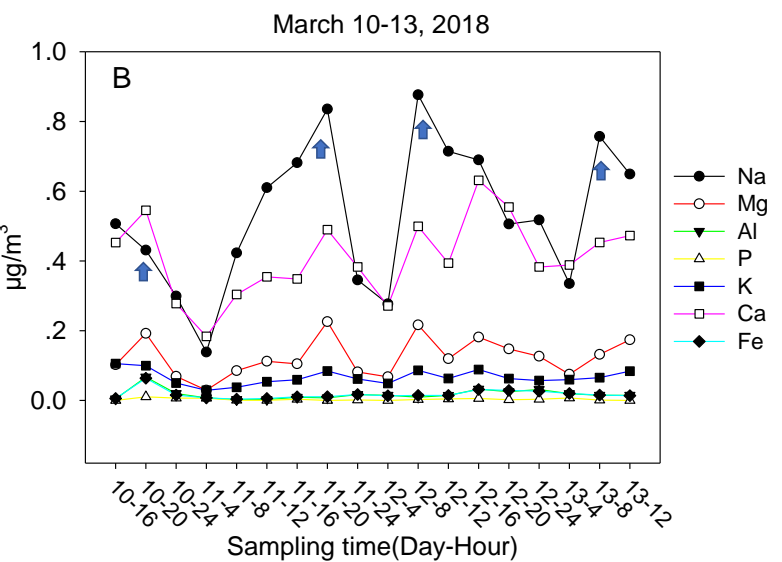

Sampling time(Day-Hour)

764 Figure 4 Time-resolved soluble elements ( $\mathrm{Na}, \mathrm{Mg}, \mathrm{Al}, \mathrm{P}, \mathrm{K}, \mathrm{Ca}$, and Fe) concentrations

in PM samples collected using the HighBioTrap sampler as described in Figure 3 during 


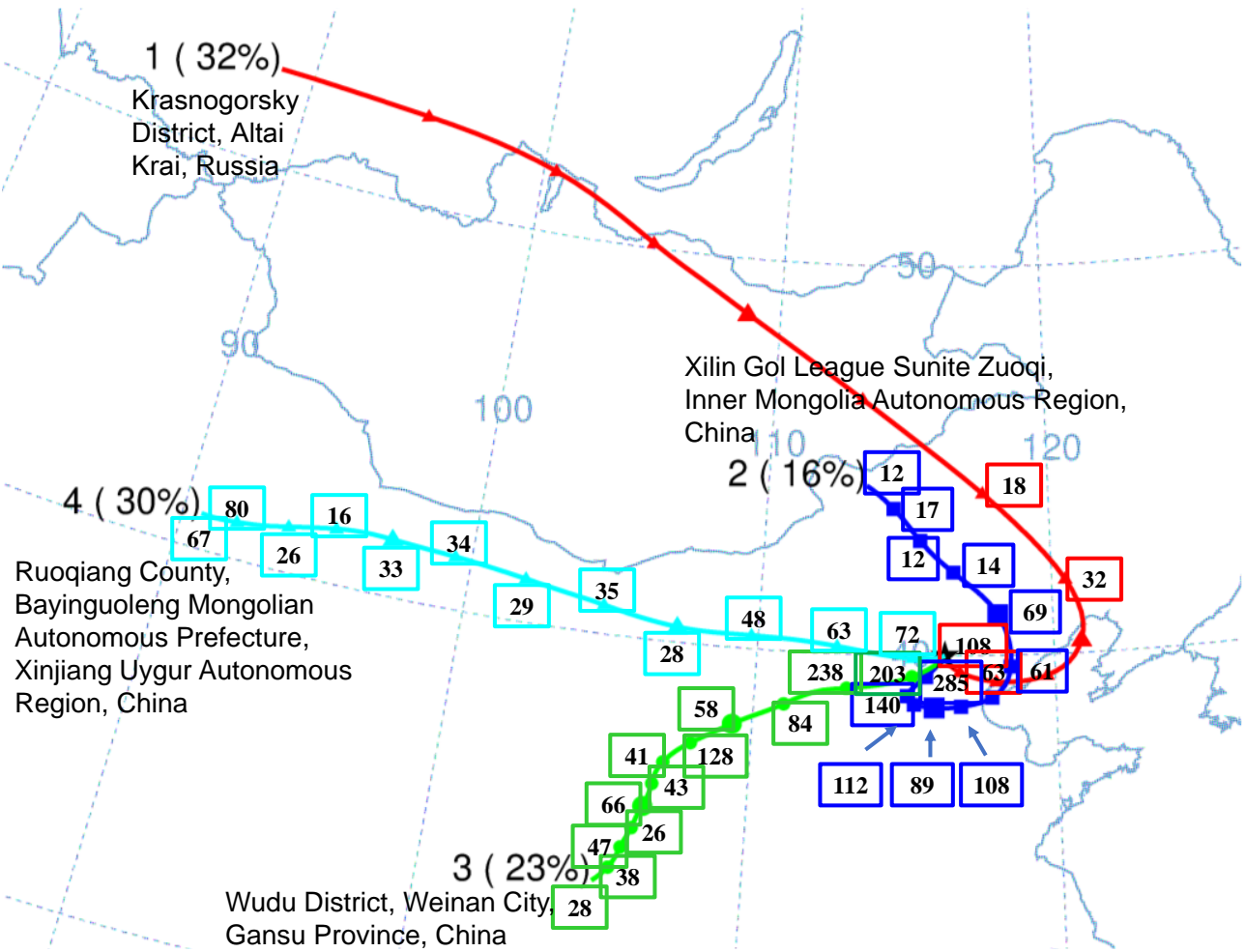

Figure 5 Air mass transport to Beijing (39.99 N 116.32 E) during the March 10-13, 2018

770 air pollution episodes using HYSPLIT Trajectory Model (NOAA) via Hysplit 4 software.

771 Numbers on four different lines represent different PM $_{2.5}$ mass concentration levels

772 (http://pm25.in/) $\left(\mu \mathrm{g} / \mathrm{m}^{3}\right)$ when the air mass across. The air mass was transported amount). 


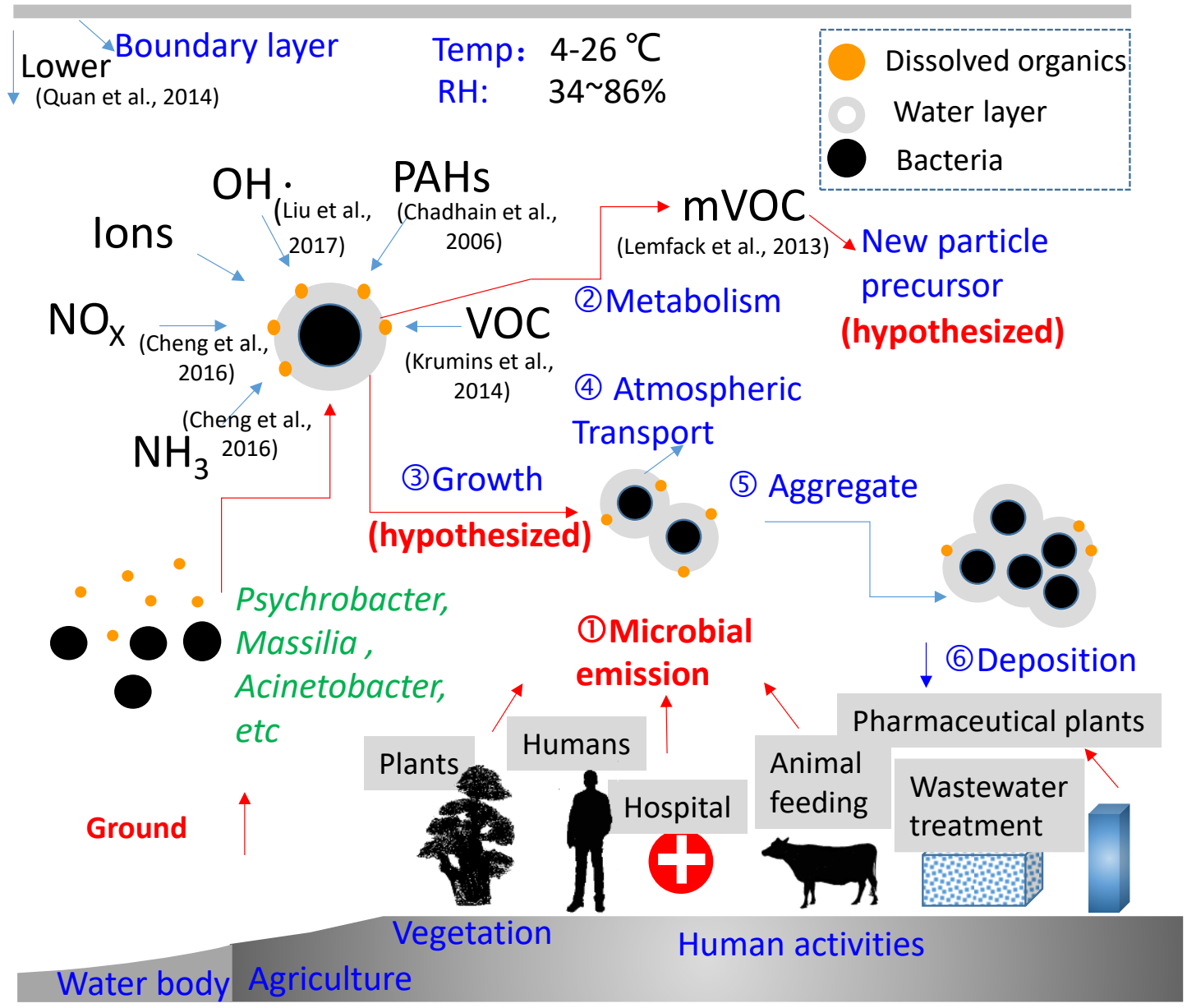

Figure 6 Hypothesized new mechanisms of bacterial growth in the air and possible roles in aerosol chemistry: Ground-emitted bacteria can uptake water vapor, $\mathrm{PAH}, \mathrm{VOC}$, $\mathrm{NH}_{3}$, NOx and release mVOCs during the growth; mVOCs could serve as new particle precursors; ultrafine particles (dissolved organics) can attach to the bacterial surface and further mix with water; newly produced bacteria can form aggregates and precipitate. 